\title{
THE SIGNIFICANCE OF NATURAL PIGMENTS USAGE TO PRODUCE INDUSTRIAL PAINTS: A SYSTEMATIC REVIEW
}

\author{
Rosa Karine Chagas ${ }^{a, b}$, Rodolfo Lopes ${ }^{b}$, Regina Rufino ${ }^{b}$, Andrea Latado ${ }^{b}$. Lilian Lefol \\ Guarieiro ${ }^{a}$, Márcio Rebouças ${ }^{a}$. \\ ${ }^{a}$ Centro Universitário SENAI CIMATEC - AV. Orlando Gomes, 1845 - Piatã - 41650- \\ 010, Salvador BA. \\ ${ }^{b}$ Ford Motor Company - Av. Henry Ford, 2000 - Copec - 42816-900, Camaçari BA.
}

\begin{abstract}
Paints have been known since ancient times and have developed over time. They are evolving and are no longer used only for aesthetic purposes and can be used for protection. With globalization, there has been considerable growth in this sector, bringing the need for new products and technologies. Due to this evolution, products that harm the environment, the population health and generate harmful waste show up. So, there has been the need to produce raw materials that do not harm the environment and do not jeopardize the well-being of humans. This study conducts a systemic review on pigments for automotive paints and natural dyes extracted from animals, also addressing the impact on the environment.
\end{abstract}

Palavras-chave: Natural Pigments; Automotive Paints, Natural Dye, Environment.

\section{A IMPORTÂNCIA DO USO DE PIGMETOS NATURAIS PARA PRODUZIR TINTAS INDUSTRAIS: UMA REVISÃO SISTEMATICA}

Resumo: A tintas são conhecidas desde os tempos primórdios e foram sendo aprimoradas ao longo do tempo. Nessa evolução, vem sendo deixandas de ser utilizadas apenas por aspecto estético, podendo ser aplicadas tambem para proteção. Com a globalização, houve um crescimento considerável deste setor, trazendo a necessidade de novos produtos e tecnologias. Assim, surgiram produtos que agridem o meio ambiente, a saúde da população e geram resíduos nocivos. Portanto, produzir matérias-primas que não agridam o meio ambiente e não comprometam o bem-estar do ser humano são totalmente necessários. Este estudo realiza uma revisão sistemática sobre pigmentos para tintas automotivas e corantes naturais de origem animal, abordando também o impacto no meio ambiente.

Palavras-chave: Pigmento Natural; Tintas Automotivas; Corante Natural, Meio Ambiente. 


\section{INTRODUCTION}

Paint is a liquid or powder product that, when applied on a substrate, forms an opaque film with decorative protective characteristics or techniques [1]. Known since the ancient times they have developed over time. In the 19th century, organic coatings emerged, considered the greatest diffusion, but it was only in the last century that the great technological development of coating compositions and raw materials occurred, and paints started to be used also for protection, especially in places where climatic conditions were more severe [2;3].

The Brazilian paint market is already consolidated. Although they often go unnoticed, paints are essential products wherever you go or in any manufactured item, e.g.: vehicles, bicycles, toys, home appliances, clothing, equipment, crafts, printing, serigraphy and construction, thus surpassing the mark of one billion liters of paints produced annually [4].

The main applications of paints are in the architectural paints market, also called decorative or real estate line, which is one of the most important segments for the paint industry. Also, the market for automotive painting and refinishing, coating for plastics and industrial maintenance [2].

Environmental protection need has also become an essential theme in the paint development sector. Processes are being studied and used that can allow and considerably reduce aggression to the environment and those who handle it. Among the main developments there is a reduction or elimination of products considered toxic in the composition of the paints.

\subsection{Paints Composition}

Regards coating concept perspective that meets all application requirements, different materials are used in a combined manner, in different quantity and presentation. Each of these components has specific functions and behaviors that assigns specific characteristics to the paints [4]. These materials that compose the paint can be grouped into four categories as shown in Table 1.

Table1. Basic Composition of the Paint. Source: The author

\begin{tabular}{|c|l|l|c|}
\hline Components & \multicolumn{1}{|c|}{ Description } & Function & References \\
\hline Solvents & $\begin{array}{l}\text { Volatile substances, which solubilize or dissolve the resin, } \\
\text { decrease the viscosity of the paint, providing fluidity } \\
\text { necessary for proper application }\end{array}$ & $\begin{array}{l}\text { Facilitate application, improve adherence } \\
\text { and control drying }\end{array}$ & {$[3 ; 5]$} \\
\hline Additives & Ingredients that provide specific paint properties & $\begin{array}{l}\text { Facilitate the dispersion of pigments, to } \\
\text { change the consistency characteristics }\end{array}$ & {$[6]$} \\
\hline Resin & Adhesion or binding material, non-volatile. & $\begin{array}{l}\text { Binding, join and adhere the pigment } \\
\text { particles, giving integrity to the paint coat }\end{array}$ & {$[7]$} \\
\hline Pigments & $\begin{array}{l}\text { Solid particles, insoluble in the medium. They are divided } \\
\text { into Organic and Inorganic }\end{array}$ & $\begin{array}{l}\text { Promotes paint color and simultaneously } \\
\text { coverage, opacity, dyeing. }\end{array}$ & {$[5 ; 8]$} \\
\hline
\end{tabular}

Details about how the pigments are divided can be checked in the table 2 
Table 2. Physical-Chemical Characteristics of Pigments. Source: BASF

\begin{tabular}{|l|c|c|}
\hline \multicolumn{1}{|c|}{ Characteristics } & Pig. Organic & Pig. Inorganic \\
\hline Thermal Resistance & Medium to Low & High \\
\hline Light fastness & Many levels & High \\
\hline Dyeing Power & High & Low \\
\hline Density & Low & High \\
\hline Variety of Colors & High & Limited \\
\hline Environmental impact & Low & Critical \\
\hline
\end{tabular}

\subsection{Dye}

Dyes are substances or a mix of substances that has the property of conferring or intensifying the products colors [11]. Colors are added to products for leastways three reasons: 1) to restore original appearance of the product after production storage and packaging process steps; 2) to make the product visually more attractive and 3) reinforce the colors already existing. The main types of existing dyes are shown in the table 3.

Table 3. Dyes Classification. Source: De Andrade Veloso

\begin{tabular}{|l|l|}
\hline \multicolumn{1}{|c|}{ Type of Dye } & \multicolumn{1}{c|}{ Obtainment } \\
\hline Organic Natural & $\begin{array}{l}\text { From vegetable, or possibly from animal, whose coloring principle has been isolated } \\
\text { using an appropriate technological process. }\end{array}$ \\
\hline \multirow{3}{*}{ Synthetic organic } & $\begin{array}{l}\text { By organic synthesis using a process appropriate technological: } \\
1 \text { - Artificial dye - synthetic organic dye not found in natural products; } \\
2 \text { - Synthetic organic dye identical to natural - whose chemical structure is similar to } \\
\text { that of the active ingredient isolated from natural organic dye. }\end{array}$ \\
\hline Inorganic & $\begin{array}{l}\text { From mineral substances and submitted to elaboration and purification processes } \\
\text { appropriate for its application. }\end{array}$ \\
\hline
\end{tabular}

There are several natural dyes types, among them we can highlight cochineal dye, produced from the bodies of Dactylopiidae female insects of the cochineal. There is evidence of its use since the tenth century. Various studies have shown that tunics and gowns were dyed with cochineal at the pre-Columbian time [10].

Currently, there is a wide cochineal application due to miscellaneous range of the red and other colors replacing synthetic dyes. This dye is stable to light, heat and the presence of oxidizing agents, it has the property of linking itself with proteins, which makes it useful in coloring milk-based products, such as yogurt, ice cream, milk drinks, meat products and biscuits, jellies and beverages, as well as pharmaceutical and textile coatings [11].

\section{METHODOLOGY}


The first stage of this systematic review is to systematize questions that will guide the survey of top publications. This study was guided by the following guiding questions:

P1) How important is cochineal for use as a natural dye?

P2) What are the most used types of pigments in automotive paints?

P3) Is there any study about the pigment obtained from natural extraction to use in the industrial paints?

After questions definition, the second stage began, which was the search process in the Google Scholar and Science Direct repositories, during the months of September 2019 to June 2020. Descriptors and combination used were: "Cochineal", "Pigment types", "Carminic acid"; "Automotive paints"; Industrial Paints. Criteria to study inclusion were: Portuguese, English and Spanish language without a defined period. Publications without a focus on complex projects, reviews, training materials were not considered.

In the stage 3 is compose of evaluation through qualifying questions with their respective weights of the publications resulting from stage 2 . The question and respective weights were:

P1) Foundations about cochineal / pigments? (weight 2);

P2) Discuss about innovation and new applications of the pigments? (weight 1);

P3) Discuss about development of new markets for cochineal / pigments? (weight 1);

P4) Production process of the cochineal dye and pigment for automotive paints? (weight 1).

Each question was answered according to notes: 1(meet), 0.5(meet partially) and 0 (do not meet). Thus, papers with a total score greater or equal than 4 or whose P1 score is equal to 1 were selected as relevant.

The overview of the systematic review is showed in the Figure 1.

Figure 1. Process Flow of the systematic review. Source: The Author

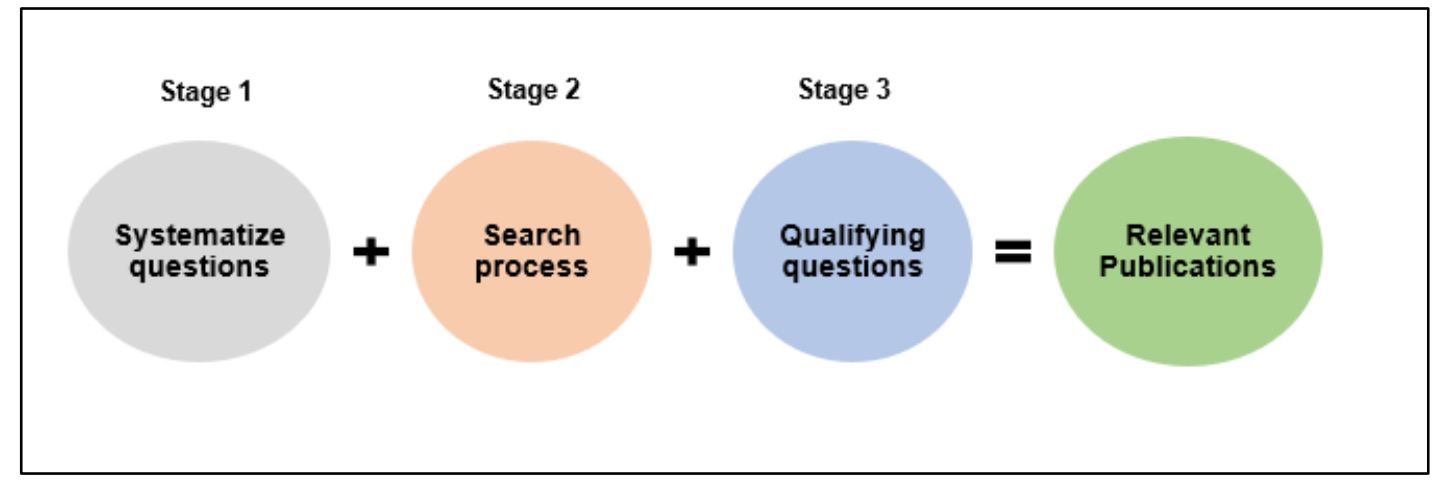

\section{RESULTS AND DISCUSSION}

Table 4 shows the results found by stages 1 and 2 defined in the methodology: 381 publications were found associated with the descriptors from September 2019 to June 2020. Step 1 of the table consists of applying the inclusion and exclusion criteria (Portuguese, English and Spanish language published without a defined period), step 2 , the terms of identification were sought in the title and summary, resulting in 37 publications and in step 3, only materials whose methodology and analysis were related to the proposed theme were considered, culminating in 24 publications. 
Table 4. Publication researched by step. Source: The Author

\begin{tabular}{|c|c|c|c|}
\hline Repositories & Step 1 & Step 2 & Step 3 \\
\hline Google Scholar & 92 & 31 & 20 \\
\hline Science Direct & 17 & 6 & 4 \\
\hline
\end{tabular}

Table 5 shows the results of the publications after the answers to the qualifying questions and in table 6 the publications that obtained satisfactory notes are presented.

Table 5. Qualification of publications selected by step 3. Source: The Author

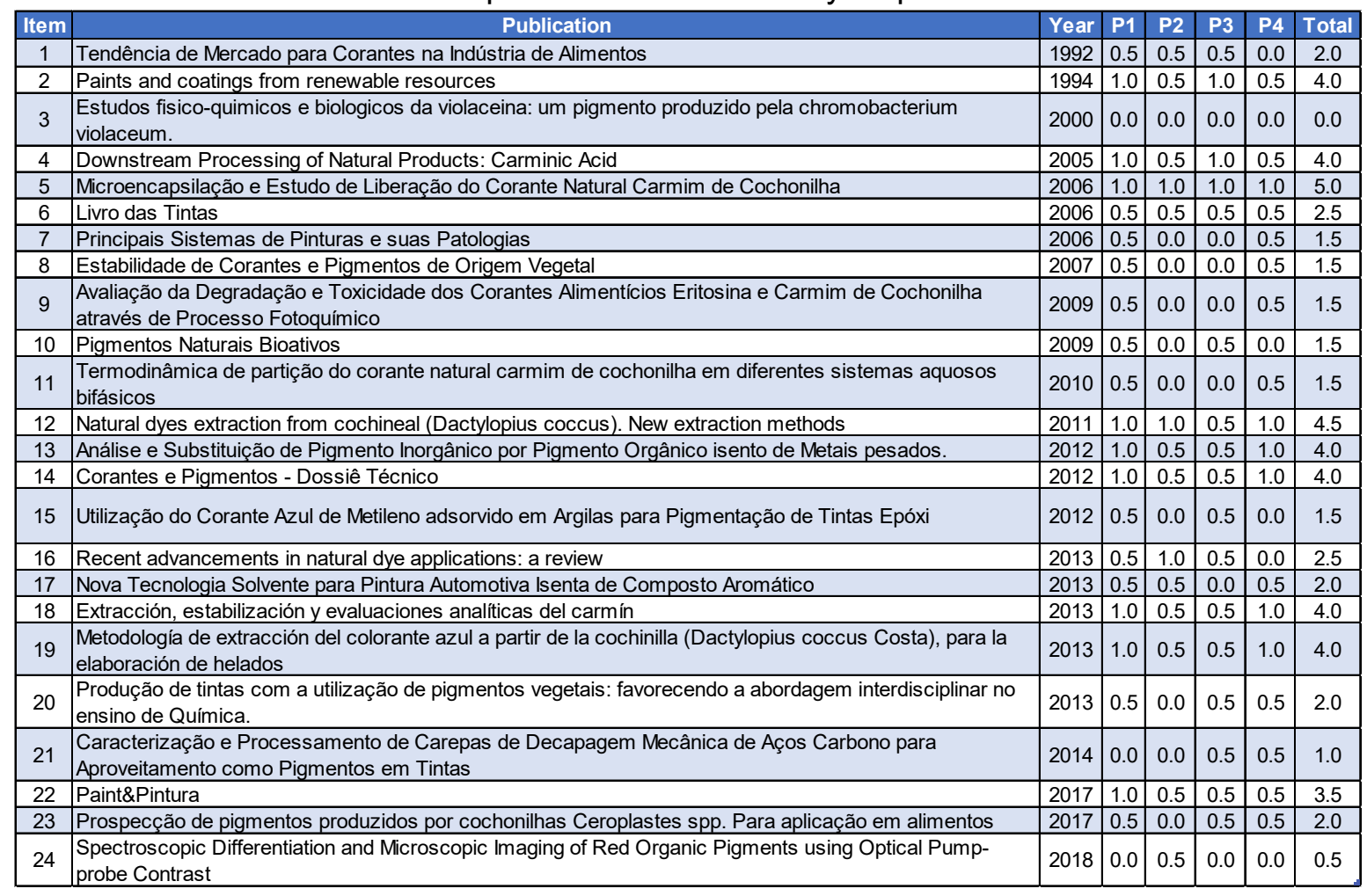

Table 6. Validation of publication quality. Source: The Author

\begin{tabular}{|c|c|c|c|c|c|c|c|}
\hline Item & Publication & Year & P1 & P2 & P3 & P4 & Total \\
\hline 1 & Microencapsilação e Estudo de Liberação do Corante Natural Carmim de Cochonilha & 2006 & 1.0 & 1.0 & 1.0 & 1.0 & 5.0 \\
\hline 3 & Paints and coatings from renewable resources & 1994 & 1.0 & 0.5 & 1.0 & 0.5 & 4.0 \\
\hline 5 & Análise e Substituição de Pigmento Inorgânico por Pigmento Orgânico isento de Metais pesados. & 2012 & 1.0 & 0.5 & 0.5 & 1.0 & 4.0 \\
\hline 6 & Corantes e Pigmentos - Dossiê Técnico & 2012 & 1.0 & 0.5 & 0.5 & 1.0 & 4.0 \\
\hline 7 & Extracción, estabilización y evaluaciones analíticas del carmín & 2013 & 1.0 & 0.5 & 0.5 & 1.0 & 4.0 \\
\hline 9 & Paint\&Pintura & 2017 & 1.0 & 0.5 & 0.5 & 0.5 & 3.5 \\
\hline
\end{tabular}

In the selected materials, it was understood the clear difference between dyes and pigments. Pigments is insoluble in the medium in which it's applied and dispersed as solid particles or crystals, whereas the dyes are soluble in the applied medium forming a molecular solution [6]. The classification according to chemical aspect between dye and pigment is shown in Table 7 . In summary, in addition to color, 
pigments, when used properly in paints, provide opacity, coverage and dyeing, while the dye only gives the color. Dyes is used in the most varied segments of the industry, such as textiles, leather goods, paper, food, cosmetics, commercial paints and plastics. Pigments is mainly used in the paint, plastics, ceramics, automotive, marine, cosmetics and other industries.

Table 7. Classification according to chemical aspect. Source: Laroca

\begin{tabular}{|c|c|c|}
\cline { 2 - 3 } \multicolumn{4}{c|}{} & DYES & PIGMENTS \\
\hline \multirow{4}{*}{ Inorganic } & \multirow{3}{*}{ Organic } & Elementary, Oxides , \\
\cline { 2 - 3 } & & Mix Oxides, Sulfets \\
\cline { 2 - 3 } & & Carbonates , Chromates, \\
\cline { 2 - 3 } & & Complex salts, Silicates \\
\cline { 2 - 3 } & Cationics & Monoazoic \\
\cline { 2 - 3 } & Anionics & Diazotics \\
\hline
\end{tabular}

It was not found in the analyzed publications the direct application of a dye from animal extraction or from plant, being used as a pigment for automotive or industrial paint to coat metallic and plastic substrates. However, all the publications expressed a need for studies about this development in general since the need for more sustainable products that least harm the environment is being requested. There is a publication with a proposal to study the physical-chemical and biological properties of a bacterial pigment [12]. In another, the prospecting of pigments produced by cochineals in food, pharmaceutical, cosmetic and textile segments is demonstrated massively, ceasing to be only a red dye and being able to have other tones of red and even other colors changing only the $\mathrm{pH}[13]$.

The largest cochineal centers production is found in the semi-arid areas of Peru, Bolivia, Chile, the Canary Islands (Spain) and Mexico. Peru leads the world production with $85 \%$ of that market. Regarding cochineal carmine, the main importer is Germany, with $19 \%$, followed by Brazil with $10 \%$ [14]. Also, it was found a publication showing the tinting power of carminic acid. Due to this, in the last 10 years, the use of this type of dye has increased the demand by almost 150\% [14]. Studies have advanced in order to innovate processes to increase production capacity and market for cochineal dye [10].

In pigments publications, it has shown that the strong trend towards natural and more sustainable products contributes to the increase of organic pigments in the composition of paints. This is because in addition to being low toxicity raw materials, it has several benefits in its use in the paints formulation, such as high tinting power, color diversity, high chromaticity, brighter, pure, intense and transparent colors, good weather resistance, excellent saturation, chemical and thermal resistance, durability, among others when compared to inorganic pigments [3][5]. Organic pigments publications cite as the most important yellow, orange and red azo pigments, blue and green copper phthalocyanines, quinacridones, indanthrones, flavantrones, quinophthalones, pyazo-quinazolones and perylenes. Perylenes from the polycyclic group pigments have wide application in the automotive industry for painting metals and plastics due to the excellent fastness to light, weather, solvents and temperature [6]. 


\section{CONCLUSION}

The analyzed publications pointed out a lack of studies on the extension of use of the natural colorant cochineal in industrial paints. The research related to this dye has basically focused on three areas: formulation and processing technology and alternative sources of pigments. They have proven to be successful and have contributed to the increase in the use of natural dyes in the food and beverage industry that already uses it. However, due to the demand for sustainable products, there is an increase in the use of organic pigments as it is non-polluting materials, also aiming to overcome some limitations of natural pigments in industrial paints. Scientific advances in chemical synthesis allowed the industrial production of many paints with that pigment in its structure.

\section{REFERENCES}

${ }^{1}$ GNECCO, Celso; MARIANO, Roberto; FERNANDES, Fernando. Tratamento de superfície e pintura. Rio de Janeiro, RJ: IBS, CBCA, 2003. p. 94.

2SILVEIRA, G. M. Avaliação dos efeitos de aditivos antiespumantes em tintas base água. Novo Hamburgo. Feevale, 2012.

${ }^{3}$ FAZENDA, Jorge M. R. (Coord.). Tintas - Ciência e Tecnologia, ABRAFATI. 4. Ed. rev. e ampl. São Paulo: Editora Edgard Blucher, 2009. p. 1124.

${ }^{4}$ REVISTA TINTAS E VERNIZES. Pigmentos. São Paulo: n. 217, Mar, 2005. p. 70.

5ZZAMUNNER, José Antônio. Tintas e Vernizes. Guarulhos, SP. 1999. p. 174.

'LAROCA, Janice. Análise e Substituição de Pigmento Inorgânico por Pigmento Orgânico insento de metais pesados, 2012.

${ }^{7}$ POLITO, Giulliano. Principais sistemas de pinturas e suas patologias. $\mathrm{BH}$, Março, 2006, p. 1-62.

${ }^{8}$ BASF. Pigmentos para tintas e vernizes. S.I. 2002. p.61.

${ }^{9}$ DE ANDRADE VELOSO, Luana. Corantes e Pigmentos - Fev 2012

${ }^{10}$ ANTONIO-CISNEROS, C. M.; DÁVILA-JIMÉNEZ, M. M.; ELIZALDEGONZÁLEZ, M. P.; GARCÍA-DÍAZ, E. Photoproducts of carminic acid formed by a composite from Manihot dulcis waste. Food Chemistry, v. 173, p. 725-732, 2015

11 SPELLMEIER, Júlia Grasiela; STÜLP, Simone. Avaliação da degradação e toxicidade dos corantes alimentícios eritrosina e carmim de cochonilha através de processo fotoquímico. Revista Acta Ambiental Catarinense, v. 6, n. 1/2, p. 65-83, 2009. 
${ }^{12}$ RETTORI, Daniel et al. Estudos fisico-quimicos e biologicos da violaceina: um pigmento produzido pela chromobacterium violaceum. 2000.

${ }^{13}$ BORGES, M. E. et al. Natural dyes extraction from cochineal (Dactylopius coccus). New extraction methods. Food Chemistry, v. 132, n. 4, p. 1855-1860, 2012.

14CRIZEL, Rosane Lopes. Prospecção de pigmentos produzidos por cochonilhas Ceroplastes spp. para aplicação em alimentos. Universidade Federal de Pelotas, Pelotas, 2017.

${ }^{15}$ Paint \& Pintura - ANO 22 - No 224 - Agosto 2017, p. 20 